\title{
Correlation of interleukin-6 with Epstein-Barr virus levels in COVID-19
}

\author{
Georg Franz Lehner', Sebastian Johann Klein ${ }^{1}$, Heinz Zoller², Andreas Peer ${ }^{1}$, Romuald Bellmann \\ and Michael Joannidis ${ }^{1 *}$ (D)
}

Keywords: COVID-19, EBV, IL-6, Inflammation, Coronavirus disease 2019, SARS-CoV-2, Severe acute respiratory syndrome coronavirus 2, Epstein-Barr virus, Interleukin-6

\section{Introduction}

Severe acute respiratory syndrome coronavirus 2 (SARS$\mathrm{CoV}-2$ ) causes coronavirus disease 2019 (COVID-19) pneumonia with respiratory failure in a subset of infected patients. To date, it is unclear which factors trigger or cause the severe course of disease. Moreover, there is only limited evidence concerning extrapulmonary manifestations of COVID-19.

We observed that COVID-19 patients invasively ventilated in our intensive care unit (ICU) showed biochemical abnormalities that resemble hepatitis and pancreatitis typically caused by herpesviruses like Epstein-Barr virus (EBV) or cytomegalia virus (CMV). Moreover, a subgroup of COVID-19 patients exhibit a hyperinflammatory pattern similar to secondary hemophagocytic lymphohistiocytosis (sHLH) [1, 2], a syndrome that can be triggered by viruses like EBV.

Thus, we speculated whether critically ill COVID-19 patients show evidence of EBV- or CMV-infection or reactivation and quantified EBV as well as CMV DNA levels in blood by PCR.

\footnotetext{
*Correspondence: michael.joannidis@i-med.ac.at

${ }^{1}$ Division of Intensive Care and Emergency Medicine, Department of Internal Medicine, Medical University Innsbruck, Anichstraße 35 6020 Innsbruck, Austria

Full list of author information is available at the end of the article
}

\section{Case series}

Herein, we report a retrospective analysis using data of the Tyrolean COVID-19 intensive care registry. We evaluated all COVID-19 patients that were treated between March 26, 2020, and April 20, 2020, in the Medical ICU at the Medical University Innsbruck, Austria, due to respiratory failure and required invasive ventilation $(n=20)$. Eighteen patients had at least one EBV and CMV PCR during ICU stay and were thus eligible for analysis. They were compared to eighteen consecutive invasively ventilated ICU patients without COVID-19.

We found that $78 \%$ of COVID-19 patients had EBV viremia, 39\% even above $1000 \mathrm{IU} / \mathrm{ml}$. Prevalence and levels of EBV viremia were significantly higher in COVID19 patients compared to non-COVID-19 patients (44.4\%, Pearson Chi-square $p=0.040$, Mann-Whitney $U$ test $p=0.022$, SPSS 26 (IBM, Armonk, NY)).

In contrast, only $17 \%$ of COVID- 19 patients and $5.6 \%$ of non-COVID-19 patients had evidence of CMV viremia, which was not significantly different between the groups (Pearson Chi-square $p=0.289$ ). No correlations between viral load of EBV and blood levels of hepatic and pancreatic enzymes or cholestasis parameters were detected.

However, there was a significant correlation between EBV viremia and interleukin-6 (IL-6) level (Fig. 1, $r=0.621, p=0.006)$ in COVID-19 patients, but not in non-COVID-19 patients $(r=-0.195, p=0.438$, Spearman's rank-order correlation). Detailed patient characteristics are outlined in Table 1. original author(s) and the source, provide a link to the Creative Commons licence, and indicate if changes were made. The images or other third party material in this article are included in the article's Creative Commons licence, unless indicated otherwise in a credit line to the material. If material is not included in the article's Creative Commons licence and your intended use is not permitted by statutory regulation or exceeds the permitted use, you will need to obtain permission directly from the copyright holder. To view a copy of this licence, visit http://creativecommons.org/licenses/by/4.0/. The Creative Commons Public Domain Dedication waiver (http://creativeco mmons.org/publicdomain/zero/1.0/) applies to the data made available in this article, unless otherwise stated in a credit line to the data. 


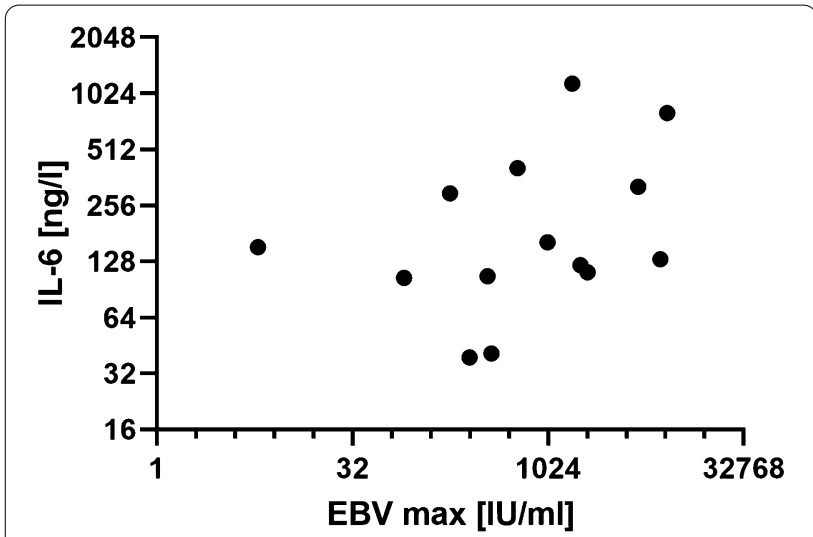

Fig. 1 Corresponding blood levels of Epstein-Barr virus (EBV) DNA and interleukin-6 (IL-6) in critically ill coronavirus disease 2019 (COVID-19) patients

\section{Discussion}

This is the first systematic report of EBV viremia in critically ill COVID-19 patients which revealed two important findings: First, COVID-19 patients have a higher prevalence of EBV viremia compared to non-COVID-19 patients. Second, levels of EBV viremia correlate with IL-6 in COVID-19 patients but not in non-COVID-19 patients.
Since EBV can induce immune dysregulation and expression of IL- 6 in peripheral blood mononuclear cells (PBMCs) via deoxyuridine triphosphate nucleotidohydrolase (dUTPase) in vitro [3], one might speculate that EBV acts as an additional inflammatory trigger in critically ill COVID-19 patients.

The observation that two patients without history of allergy but an EBV viremia above $1000 \mathrm{IU} / \mathrm{ml}$ developed a generalized maculopapular rash following administration of amoxicillin/clavulanate and piperacillin/tazobactam, further emphasizes the hypothesized immunological impact of EBV in this setting $[4,5]$.

Although this observation was made in a limited number of patients in a retrospective analysis, the systematic approach based on registry data minimizes the risk of selection bias. Moreover, we compared COVID-19 patients to an appropriate control group. The findings concerning EBV and CMV viremia in the control group are in accordance with previously reported cumulative incidences (i.e., $48 \%$ and 18\%, respectively) [6].

\section{Conclusion}

These data suggest that EBV viremia is highly prevalent in COVID-19 patients with respiratory failure and associated with systemic inflammation as evidenced by high IL-6 levels. It remains to be elucidated whether EBV

Table 1 Overview of parameters (median (25th-75th percentiles) and \# median (25th percentile)) between coronavirus disease 2019 (COVID-19) patients with and without EBV viremia and non-COVID-19 patients

\begin{tabular}{|c|c|c|c|c|}
\hline & COVID-19 $(n=18)$ & $\begin{array}{l}\text { COVID-19 } \\
\text { EBV negative }(n=4)\end{array}$ & $\begin{array}{l}\text { COVID-19 } \\
\text { EBV positive }(n=14)\end{array}$ & $\begin{array}{l}\text { Non-COVID-19 } \\
(n=18)\end{array}$ \\
\hline Age (years) & $\begin{array}{l}60.5 \\
(52.0-64.5)\end{array}$ & $\begin{array}{l}45.5 \\
(43.3-59.0)\end{array}$ & $\begin{array}{l}61.5 \\
(53.8-66.8)\end{array}$ & $\begin{array}{l}58.8 \\
(47.8-72.3)\end{array}$ \\
\hline IL-6 (ng/l) & $\begin{array}{l}125.1 \\
(40.5-302.8)\end{array}$ & $\begin{array}{l}20.9 \\
(18.0-101.4)\end{array}$ & $\begin{array}{l}142.0 \\
(106.0-342.4)\end{array}$ & $\begin{array}{l}85.7 \\
(43.6-377.4)\end{array}$ \\
\hline CRP (mg/dl) & $\begin{array}{l}14.6 \\
(4.3-16.6)\end{array}$ & $\begin{array}{l}5.8 \\
(2.2-14.8)\end{array}$ & $\begin{array}{l}15.5 \\
(7.7-19.7)\end{array}$ & $\begin{array}{l}8.3 \\
(3.7-28.1)\end{array}$ \\
\hline PCT $(\mu \mathrm{g} / \mathrm{l})$ & $\begin{array}{l}0.3 \\
(0.2-0.8)\end{array}$ & $\begin{array}{l}0.2 \\
(0.1-0.4)\end{array}$ & $\begin{array}{l}0.4 \\
(0.2-1.1)\end{array}$ & $\begin{array}{l}1.3 \\
(0.2-6.8)\end{array}$ \\
\hline Bilirubin total (mg/dl) & $\begin{array}{l}0.9 \\
(0.4-1.2)\end{array}$ & $\begin{array}{l}0.67 \\
(0.4-0.9)\end{array}$ & $\begin{array}{l}1.0 \\
(0.4-1.3)\end{array}$ & $\begin{array}{l}0.7 \\
(0.5-2.6)\end{array}$ \\
\hline ASAT (U/I) & $\begin{array}{l}67.5 \\
(33.5-91.8)\end{array}$ & $\begin{array}{l}63.0 \\
(18.8-114.0)\end{array}$ & $\begin{array}{l}67.5 \\
(33.5-85.8)\end{array}$ & $\begin{array}{l}51.0 \\
(38.5-122.3)\end{array}$ \\
\hline $\operatorname{ALAT}(\mathrm{U} / \mathrm{I})$ & $\begin{array}{l}49.0 \\
(37.5-80.5)\end{array}$ & $\begin{array}{l}73.5 \\
(20.5-185.75)\end{array}$ & $\begin{array}{l}49.0 \\
(40.5-72.3)\end{array}$ & $\begin{array}{l}56.0 \\
(23.8-194.8)\end{array}$ \\
\hline GGTP $(\mathrm{U} / \mathrm{I})$ & $\begin{array}{l}173.0 \\
(61.5-370.0)\end{array}$ & $\begin{array}{l}206.5 \\
(8.8-657.0)\end{array}$ & $\begin{array}{l}151.5 \\
(60.3-370.0)\end{array}$ & $\begin{array}{l}131.5 \\
(76.5-305.0)\end{array}$ \\
\hline $\mathrm{AP}(\mathrm{U} / \mathrm{I})$ & $\begin{array}{l}103.5 \\
(79.0-222.0)\end{array}$ & $\begin{array}{l}131.0 \\
(102.3-273.8)\end{array}$ & $\begin{array}{l}93.0 \\
(57.3-222.0)\end{array}$ & $\begin{array}{l}220.5 \\
(175.5-559.3)\end{array}$ \\
\hline Amylase (U/I) & $\begin{array}{l}37.0 \\
(24.5-67.0)\end{array}$ & $\begin{array}{l}37.0 \\
(22.0) \#\end{array}$ & $\begin{array}{l}43.0 \\
(23.3-71.8)\end{array}$ & $\begin{array}{l}39.0 \\
(15.0-48.0)\end{array}$ \\
\hline Lipase (U/I) & $\begin{array}{l}43.0 \\
(21.0-75.0)\end{array}$ & $\begin{array}{l}26.0 \\
(26.0) \#\end{array}$ & $\begin{array}{l}47.5 \\
(19.3-74.0)\end{array}$ & $\begin{array}{l}30.0 \\
(16.0-66.0)\end{array}$ \\
\hline
\end{tabular}

EBV, Epstein-Barr virus; ICU, intensive care unit; IL-6, interleukin-6; PCT, procalcitonin; CRP, c-reactive protein; ASAT, aspartate aminotransferase; ALAT, alanine aminotransferase; GGTP, gamma glutamyltransferase; AP, alkaline phosphatase 
viremia represents an epiphenomenon in COVID-19 or plays a pathogenetic role as additional trigger of a systemic inflammatory response in this setting.

\section{Abbreviations}

SARS-CoV-2: Severe acute respiratory syndrome coronavirus 2; COVID-19: Coronavirus disease 2019; EBV: Epstein-Barr virus; CMV: Cytomegalia virus; sHLH: Secondary hemophagocytic lymphohistiocytosis; ICU: Intensive care unit; IL-6: Interleukin-6; PBMCs: Peripheral blood mononuclear cells; dUTPase: Deoxyuridine triphosphate nucleotidohydrolase; PCT: Procalcitonin; CRP: C-reactive protein; ASAT: Aspartate aminotransferase; ALAT: Alanine aminotransferase; GGTP: Gamma glutamyltransferase; AP: Alkaline phosphatase.

\section{Acknowledgements}

Not applicable.

\section{Authors' contributions}

GFL and MJ had the idea and developed the concept. GFL analyzed the data and wrote the manuscript. SJK, HZ, AP, and RB treated patients, collected data, and revised the manuscript. All authors read and approved the final manuscript.

\section{Funding}

There was no funding for this study.

Availability of data and materials

No data are publicly available at this time.

\section{Ethics approval and consent to participate}

This study was approved by the ethics committee of the Medical University Innsbruck (\# 1099/2020).

\section{Consent for publication}

Not applicable-manuscript contains no individual patient data.

\section{Competing interests}

None of the authors has any conflicts of interest to declare.

\section{Author details}

${ }^{1}$ Division of Intensive Care and Emergency Medicine, Department of Internal Medicine, Medical University Innsbruck, Anichstraße 35, 6020 Innsbruck, Austria. ${ }^{2}$ Internal Medicine I, Department of Internal Medicine, Medical University Innsbruck, Anichstraße 35, 6020 Innsbruck, Austria.

Received: 28 Auqust 2020 Accepted: 12 November 2020

Published online: 23 November 2020

\section{References}

1. Huang C, Wang Y, Li X, Ren L, Zhao J, Hu Y, et al. Clinical features of patients infected with 2019 novel coronavirus in Wuhan, China. Lancet. 2020:395(10223):497-506.

2. Mehta P, McAuley DF, Brown M, Sanchez E, Tattersall RS, Manson JJ, et al. COVID-19: consider cytokine storm syndromes and immunosuppression. Lancet. 2020;395(10229):1033-4.

3. Glaser R, Litsky ML, Padgett DA, Baiocchi RA, Yang EV, Chen M, et al. EBVencoded dUTPase induces immune dysregulation: implications for the pathophysiology of EBV-associated disease. Virology. 2006;346(1):205-18.

4. LeClaire AC, Martin CA, Hoven AD. Rash associated with piperacillin/tazobactam administration in infectious mononucleosis. Ann Pharmacother. 2004;38(6):996-8.

5. Thompson DF, Ramos CL. Antibiotic-induced rash in patients with infectious mononucleosis. Ann Pharmacother. 2017;51(2):154-62.

6. Ong DSY, Bonten MJM, Spitoni C, Lunel FMV, Frencken JF, Horn J, et al. Epidemiology of multiple herpes viremia in previously immunocompetent patients with septic shock. Clin Infect Dis. 2017;64(9):1204-10.

\section{Publisher's Note}

Springer Nature remains neutral with regard to jurisdictional claims in published maps and institutional affiliations.
Ready to submit your research? Choose BMC and benefit from:

- fast, convenient online submission

- thorough peer review by experienced researchers in your field

- rapid publication on acceptance

- support for research data, including large and complex data types

- gold Open Access which fosters wider collaboration and increased citations

- maximum visibility for your research: over $100 \mathrm{M}$ website views per year

At $\mathrm{BMC}$, research is always in progress.

Learn more biomedcentral.com/submissions 